\title{
Geçmişin çeviri yoluyla anlatısında güç mücadeleleri
}

\section{Hilal ÖZTÜRK BAYDERE1}

APA: Öztürk Baydere, H. (2019). Geçmişin çeviri yoluyla anlatısında güç mücadeleleri. RumeliDE Dil ve Edebiyat Araşturmaları Dergisi, (15), 401-412. DOI: 10.29000/rumelide.606237.

\section{$\ddot{\mathbf{O} z}$}

$\mathrm{Bu}$ çalışmanın amacı bir İngiliz'in Osmanlı esareti altındaki anılarını anlatan Captured at Kut: Prisoner of the Turks'ün (2008) Türkçeye yapılmış Esir Bir İngiliz Doktorun Kûtülamare Anılar (2018) başlıklı çevirisi üzerinden, kaynak metin ile çeviri metin arasında dipnotlar bağlamında var olduğu gözlemlenebilen karşıt anlatıları çeviribilimsel bir bakış açısıyla ele almaktır. Kaynak metin W. C. Spackman'ın Basra'nın işgali ile başlayan ve esir alındığı dönemi de kapsayan anılarını anlatmaktadır. Spackman, bu dönem içinde tuttuğu günlük ve notlardan yola çıkarak bu kitabı bir araya getirmiştir. Kendisi, doktorluk görevinden ötürü dolaşım serbestliğine sahip olduğu için, dönemi ve içinde bulunduğu ortamı "bir seyyah gibi" (W. C. Spackman, 2018) kaleme alma imkânı bulmuştur. Spackman bu kitabı ölmeden önce bir araya getirmiş olsa da yayımlanması kendisinin ölümünden sonra gerçekleşmiştir. Kitabı İngilizcede yayına hazırlayan yeğeni Anthony Spackman “anlatılanların akışındaki düzeni değiştirme[diğini]” ve “önemli ayrıntılara dokunmadı[ [̆ını]”, sadece olaylara açıklık getirmek amacıyla kimi cümlelerde "ufak tefek değişiklikler yaptı[ğını]" belirtmektedir (A. Spackman, 2018: xiv). Diğer taraftan, yayın danışmanı Mesut Uyar'ın metnin Türkçe çevirisine yazdığı önsözdeki otobiyografik özellikler taşıyan bu türden eserlerin "taraflı aktörler[ce]" (Uyar, 2018: xx) kaleme alındığı, dolayısıyla eksik bilgiler verdiği yönündeki iddiasının, metni çeviribilim bağlamında irdelemeye değer kıldığı düşünülmektedir. Bu çalışmada, Uyar’ın bu ifadesiyle ilişkilendirilebilecek dipnotlar üzerinden betimleyici bir çalışma yürütülerek, geçmişi anlatan metinlerde ve çevirilerinde anlatının nasıl bir güç mücadelesine dönüştüğü ortaya koyulmaya çalışılacaktır.

Anahtar kelimeler: Güç mücadelesi, anı, yeniden yazım, metinsiz geri çeviri, tarih yazımı.

\section{Power struggles in the narration of the past through translation}

\begin{abstract}
This study seeks to analyze the counter narratives in Captured at Kut: Prisoner of the Turks (2008), which tells the memoirs of an Englishman captured by the Ottoman, and its Turkish translation titled Esir Bir İngiliz Doktorun Kûtülamare Anılar [Memoirs of Kut by a Captive British Medical Doctor] (2018) as manifested in footnotes from a Translation Studies perspective. Captured at Kut relates the experiences and observations of Regimental Medical Officer W. C. Spackman in the Mesopotamian Campaign, from the English invasion of Basra through the siege of Kut, as well as the seven months he was held as a prisoner of war. Since Spackman was a medical doctor, he was considered to be on parole, which gave him a chance to observe local people and customs in the region. He wrote about his experiences like a "traveler" (W. C. Spackman, 2018), and his memoirs were published posthumously by his nephew, Anthony Spackman. In his preface, Anthony Spackman states that he
\end{abstract}

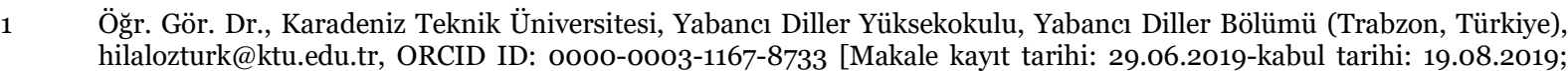
DOI: 10.2900o/rumelide.606237] 
did not alter "the structure of the narrative, nor any of its essential details" but "attempted to clarify [...] and rephrase" the narrative when necessary (2008, Preface). However, Mesut Uyar, the editorial consultant of the Turkish translation, states that authors of works of this nature are "biased actors" (2018: xx), and they offer incomplete information about the events. This statement of Uyar is considered significant to scrutinize the work within the context of Translation Studies. This study attempts to provide a descriptive account of how the narration of the past transforms into a power struggle in translation based on the footnotes that can be associated with Uyar's above-mentioned claim.

Keywords: Power struggle, memoir, rewriting, textless back translation, historiography.

\title{
1. Giriş
}

Çeviri kuramı, yüzyllar boyunca nesnel ve sabit olan anlamların (Chesterman ve Arrojo, 2017: 17) yazarının kontrolünde bulunduğu anlayış çerçevesinde şekillenmiştir. Bunun sonucu olarak da çeviri olgusu "çeviri” - "özgün” ve "çevirmen” - "yazar" gibi ikili karşıtlıklar çerçevesinde ele alınmış, çeviri de ikincil konuma itilmiştir. Ancak, yapısalcılık sonrası süreç içinde gelişen bakış açısıyla çeviriye yönelik bu geleneksel bakış açısı da sorgulanmaya başlamıştır. "The Revision of the Traditional Gap between Theory \& Practice \& the Empowerment of Translation in Postmodern Times" (1998) isimli makalesinde Rosemary Arrojo, çevirilerin ve çevirmenlerin gerçek koşullarının göz ardı edildiğini belirtmekte ve tüm yönleriyle gerçekleştirilmesi imkânsız olan eşdeğerlik arayışının çeviri ve çevirmenlere yönelik bakışa yansımasını şu sözlerle açıklamaktadır:

\begin{abstract}
Çevirmenin yaptığı işin görünmez ve ideal olarak tarafsız olması gerektiği şeklindeki çok eski ilkeyi tekrar tekrar tasdik eden yaklaşımlarda mantıksallık ve sözde evrensel etik gereği gerçek çevirmenlere ve onların koşullarına neredeyse hiç yer verilmemesi mutlak değerlerin ve evrensel modellerin peşinde gidildiğinin kesin bir göstergesidir [...] Anlam eğer tıpkı hakikat gibi özünden herhangi bir şey kaybetmeden dolaştırabildiğimiz sabit bir öze benziyorsa çevirmen de temelde mekanik bir görevi (taşınan şeyin içeriğine müdahale etmeden anlam aktarımının güvenli şekilde sağlanması) bulunan görünmez bir taşıyıcı işlevi görecektir. Bu anlayışa göre çeviri esasen bir eşdeğerlik sağlama biçimidir ${ }^{2}$ (39-40).
\end{abstract}

Çeviriyi içinde bulunduğu koşullardan bağımsız bir şekilde sadece anlam aktarımı olarak gören bu anlayış kaynak metindeki anlamı odak noktasına aldığı için metnin anlamına ve oluşturulma sürecine ilişkin yetkiyi de yalnızca yazara vermektedir. Bu nedenle, bu bakış açısına göre çeviri özgünden, çevirmen de yazardan alt konumdadır.

Judy Wakabayashi de çevirinin genelde "pasif, otomatik ve [...] 'zaten söylenmiş olanı' aktaran sorunsuz bir süreç” (2010: 89) olarak görüldüğüne değinmektedir. Bu açıdan bakıldı̆̆ında, çevirmenlerin sadece "yazarın sesini” aktaran bir aracı olarak görülmesi söz konusudur (89). Halbuki, çeviri bir anlatıda duyduğumuz sadece yazarın değil aynı zamanda çevirmenin de sesidir (Hermans, 1997: 65). Bunun yanı sıra, bir metnin çeviri sürecine girmesinden satışına sunulmasına kadar geçen süre içerisinde pek çok düzenlemeden geçtiği muhakkaktır. Bu düzenlemelerde rol oynayan eyleyicilerin "farklı öznellikleri, kişisel gündemleri ve kültürel politikaları” (Bush, 2012: 119) da belirli bağlamlar içerisinde gerçekleşen yayımlanma sürecinin bir parçası olmaktadır. Tarihsel süreç içerisinde etkileşimde bulunmuş topluluklara ait ortak bir tarih anlatısının söz konusu olduğu eserlerde ise bahsi geçen "kültürel politikalar" ve "kişisel gündemler" çeviri sürecinde çok daha fazla ön plana çlkabilmektedir. 


\section{2. Çeviribilimde otorite kavramı}

"Çeviri” - "özgün” ve "çevirmen” - “yazar” arasındaki ilişkiler üzerine geliştirilen söylemlerde geleneksel olarak "otorite" ve anlamı kontrol hakkı yazara ve kaynak metne atfedilmiştir. Bu bağlamda çevirmenin üstlendiği rol ise kaynak metindeki anlamın aktarımına yardımcı olmak ve aracılık etmek olmuştur. Özcülük karşıtı anlayış ile birlikte ise yazarlar ve metnin yorumlayıcıları arasındaki ilişkinin bir "iş birliği” ilişkisi olmadığı iddia edilmiş, aksine, belirli bir bağlamda ve belirli koşullar altında (geçici olarak) neyin doğru ve kesin olduğuna karar verme hususunda iki taraf arasında gerçekleşen bir güç mücadelesi olduğu vurgulanmıştır (krş. Arrojo, 2002: 73). Bu güç mücadelesinin, tarihi metinler söz konusu olduğunda daha da ön plana çıktığı söylenebilir. Zira, aynı tarihi olayın müşterek paydaşları açısından bakıldığında, tarihi yazan kişinin aynı zamanda onu şekillendiren kişi olduğu ve çeviri sürecinde de aynı tarihin iki kez farklı eyleyiciler tarafından şekillendirilmesinin söz konusu olduğu söylenebilir. Bu bağlamda, tarih anlatısında bulunan metinlerde sözü edilen güç mücadelesinin daha da ön planda olması beklenebilir.

Çevirmenler neyin nasıl olması gerektiğini bilen uzman kişiler olmalarına (Vermeer, 2000: 231) ve aldıkları kararların sorumluluğunu taşıyan özneler olarak metin üretim sürecinin aktif eyleyenleri arasında bulunmalarına rağmen, otorite açısından yapılan değerlendirmelerde bu hususlar çoğunlukla göz ardı edilmektedir. Özgün metni yazarların kastettikleri "gerçek" anlamları içeren "kapalı ve sabit bir alan" olarak gören anlayış, "bir metnin barındırdığı 'gerçeği' belirleme yolunda sergilenen güç mücadelesinde, anlamların ancak 'gerçek sahipleri' olan yazarlarca belirlenebileceğini” savunur (Arrojo, 2002: 73). Dolayısıyla, yazarların "metinsel 'mülkiyetlerine' girme cesaretini gösteren herkesin bu hak sahiplerine koşulsuz bir saygı göstermesi” gerektiği düşüncesi hala yaygınlığını korumaktadır (73-74).

"The Translator as Non-Author, and I am Sorry About That" (2009: 32) isimli makalesinde Anthony Pym, yazarlığın birkaç farklı şekilde ele alınabileceğine değinmektedir. Çevirmenlerin yazar konumunda görülmesi gerektiği düşüncesini irdeleyen çalışmada yazarlık kavramının, metnin otoritesine sahip olmanın, sadece yaratıcılık ve bireysellik bağlamında değerlendirilemeyeceği, etik bir sorumluluğu da beraberinde getirdiği belirtilmektedir. Araştırmacıya göre bu husus, çevirmenlere yazarlık statüsü atfetmeyi sağlayan edebi ideolojilerin göz ardı ettiği bir konudur (krş. 32). Pym, biçimsel edimbilimden ödünç aldığı çeşitli kavramlarla çevirmenlere ilişkin şöyle bir çıkarımda bulunmaktadır: çevirmenlerin, yazarın ya da kaynak metnin doğruluğuna ya da haklılığına ilişkin herhangi bir iddialarının olması beklenmez. Bu yüzden çevirmenler, kaynak metinlerin doğruluğunu ispatlamakla yükümlü değildir. Zaten çevirmenliği yazarlıktan ayıran şey de budur (krş. 36). Diğer bir deyişle, Pym'e göre, metnin anlamına ilişkin otorite de yazarın elindedir. Ancak burada, Pym’in argümanlarını dayandırdığı kuramın dilbilimle ilişkili olması dikkat çekicidir. Çeviribilim özerk bir bilim dalı haline gelmeden önce dilbilimin sağlam bilimsel prensiplerinden faydalanmış, bunun sonucu olarak da dilbilim temelli pek çok çeviri kuramı ortaya çıkmıştır (Karadağ, 2006: 254-255). Bu kuramların ortak odak noktalarından biri de bir iletişim biçimi olarak gördükleri çeviride eşdeğerliğin amaç olarak benimsenmesi olmuştur ve bu da "çeviri uygulamasından kopuk bir görüntü[nün]" ortaya çlkmasına neden olmuştur (Bulut, 2000: 74). Bu bakış açısının da çevirmenlerin yazar ve otorite sahibi olarak görülmelerini imkânsız kıldığı savunulabilir. Buna paralel şekilde, çeviri metinler bağlamında kaynak metnin doğruluğu değil çeviri metnin kaynak metni temsiliyeti ve bu temsiliyetin derecesi sorgulanmaktadır.

Odağında eşdeğerlik kavramı yer alan bu bakış açısına karşı çıkan çağdaş çeviribilimciler çevirinin tarihsel bağlamından kopuk bir olgu olarak ele alınmasına karşı çıkmışlar (Hermans, 2014: 11), çevirinin bir "yeniden yazım" (Lefevere, 1992: 9) olduğunu belirtmişlerdir. Bu görüşe göre, "her tür yeniden yazım 
manipülasyon içer[mekte]" (9) ve "yeniden yazarlar çoğunlukla özgün metinleri üretildikleri dönemin baskın ideolojik ve poetik akımına ya da akımlarından birine uygun hale getirmek üzere” onları uyarlamakta ve manipüle etmektedir (krş. 8).

Çevirinin ideolojik doğasının dikkate alınmaması ve çevirinin şeffaf, bire bir aktarım süreci olarak görülmesi ise çeviri metnin üretim sürecinde aktif rol oynayan koşulların göz ardı edilmesine neden olmaktadır. Bu anlamda, çeviriyi bir aktarımdan ziyade "dönüştürüme" (Derrida, 1982: 20) dayanan "yeniden yazım" olarak değerlendirmek, metnin üretildiği kültürel ve tarihsel koşulların ve üretim sürecine dahil olan eyleyicilerin bütüncül olarak değerlendirilmesini sağlayabilecektir. Özetlemek gerekirse, "çağdaş çeviribilim çerçevesinde ileri sürülen kuramsal görüşlerde [...] vurgunun özellikle 'kültür' ve 'ideoloji' üzerinde yoğunlaştı̆̆ çevirmenin yaptı̆̆ çeviriyle 'görülebilir' olduğu” (Karadağ, 2003: 29) söylenebilir.

\section{Bir anı olarak Captured at Kut: Prisoner of the Turks ve metinsiz geri çevirisi}

Captured at Kut: Prisoner of the Turks, W. C. Spackman'in 48. Savaş İstihkâm Taburu'nun doktoru olarak görev yaptığı dönemde Mezopotamya Harekâtı'nın Kûtülamare'nin Halil Paşa tarafından kuşatılıp teslim alınmasına kadarki sürecini anlattığı günlük ve tuttuğu notlardan oluşturulmuş bir kitaptır. Spackman'ın savaş sırasında günlük tuttuğu, günlük tutamadığı zamanlarda ise notlar aldığı belirtilmektedir. Savaş sonrasında İngiltere'ye geri dönen Spackman, diğer askerlerin anılarını okuyarak ve gerektiğinde onlarla görüşmeler yaparak kendi metnine eklemeler yapmış ve anılarını derlemiştir. Ancak bu anıların kitap olarak basılması W. C. Spackman'ın ölümünden sonra, anıların yeğeni Anthony Spackman tarafından keşfedilmesiyle gerçekleşmiştir.

Anthony Spackman bu derlenmiş haliyle amcasının kitabını ölümünün ardından bastırmış ve kitaba yazmış olduğu "Sunuş" yazısında bu sürece olan dâhiliyetini şu şekilde açıklamıştır:

Anlatılanların akışındaki düzeni değiştirmediğim gibi önemli ayrıntılara da dokunmadım [...] Ara sıra hikâyeye açıklık getirmek gayesiyle kimi cümlelerinde ufak tefek değişiklikler yaptım. Ancak bunu yaparken amcamın okuyucuya aksettirmek isteyeceği tarzı bozmadığıma inanıyorum. Ne yazık ki kendisi hayattayken bu günlükten haberim yoktu, dolayısıyla hiçbir ayrıntıyı karşılıklı konuşma firsatım olmadi (A. Spackman, 2018: xiv-xv).

Eserin Türkçe çevirisi ise Esir Bir İngiliz Doktorun Kûtülamare Anıları ismiyle İş Bankası Kültür Yayınları tarafından "anı" kategorisinde yayımlanmıştır. Türkçe çevirisi Derin Türkömer tarafından yapılan kitabın yayın danışmanlığını askeri tarih uzmanı Mesut Uyar yapmıştır. Uyar’ın ‘Türkçe Baskıya Önsöz" kısmındaki ifadelerinin Türk okuyucuların bu kitaba karşı ne tür bir tutum sergilemeleri gerektiğine ilişkin bir uyarı niteliğinde olduğu söylenebilir:

Türkiye'de Birinci Dünya Savaşı'nda meydana gelenleri bütün boyutlarıla ve tarafsız bir şekilde 3 kaleme alan bilimsel eserler az olduğu ve resmi tarih kitapları okuyucuların istek ve beklentilerini karşılamadı̆̆ı için hatıralar birer tarih kitabı muamelesi görmektedir. Anı yazarlarının tarafsız tarihçiler değil tam tersine oldukça taraflı aktörler oldukları, küçük bir pencereden büyük bir savaşa baktıkları, bazı konuları bütün detaylarıyla aktarırken en az onun kadar önemli diğer konuları ihmal ettikleri unutulmaktadır. Üstelik anı yazarlarının isteseler bile olayların hızlı akışı içinde bütün hadiselere şahit olup ve deneyimlerini tamamıyla ve dürüstçe kaleme almalarını beklemek büyük bir yanılgıdır (Uyar, 2018: $\mathrm{xx}$ ). 
$\mathrm{Bu}$ alıntıdan anlaşılabileceği üzere, yayın danışmanı Uyar tarih kitaplarının tarafsız olabileceğine ilişkin inancına karşın söz konusu kitabın "tarafsız" bir "tarih kitabı" olarak görülmemesi gerektiğine dikkat çekmektedir. Uyar'ın, metnin ait olduğu tür itibarıyla “dürüst[lükten]” ve nesnellikten uzak olabileceğini vurgulayarak okuru belirli bir doğrultuda yönlendirdiği iddia edilebilir.

İlgili metinlerin üretim süreçlerine bakıldığında hem kaynak metnin hem de erek metnin birden fazla kişinin müdahalesine tabi olduğu görülmektedir. Kaynak dizgedeki metnin şekillenmesinde William C. Spackman'ın kendi anılarının yanı sıra, kendisine yakın tarihlerde ilgili bölgede görev yapmış olan diğer askerlerin anılarından faydalanmış olması dikkat çekicidir. Ayrıca, Anthony Spackman'ın metne yapmış olduğu müdahaleler de söz konusudur. Bu anlamda, Anthony Spackman bu değişiklikleri "ufak tefek" olarak nitelendiriyor olsa da İngilizce metnin Türkçeye çevrilmeden önce bir diliçi çeviri sürecinden geçtiği söylenebilir. Bu durum kendi içinde değerlendirilebilecek olsa da belirtilen günlükler ve notlar genel okuyucu kitlesi tarafından ulaşılabilir olmadığından kaynak metnin üretim sürecindeki müdahaleler bu çalışmanın kapsamının dışında tutulmuştur.

Yan metinlerinden elde edilen bu bilgiler ışığında kaynak metnin bir "anı" ve çevirisinin de bir "metinsiz geri çeviri” (Wang, 2015; aktaran Tu ve Li, 2017: 2-3), olması itibarıla bu kavramlara kısaca değinmenin yerinde olacağı düşünülmektedir.

\title{
3.1. Bir metin türü olarak "Anı"
}

Nazan Aksoy Kurgulanmış Benlikler: Otobiyografi, Kadın, Cumhuriyet (2018) isimli kitabında anıyı otobiyografinin bir türü olarak ele almaktadır (9). Aksoy otobiyografiyi ise şu şekilde tanımlamaktadır: "Otobiyografi yazarın yazma işine koyulduğu noktadan geçmişine bakması ve hafızanın yardımıyla o güne kadarki hayatını metinleştirmesi, yani geçmişini kalıcı kılma gayretidir" (13). Buradan da anlaşılacağı üzere, otobiyografinin neyi, nasıl kapsayacağı yazarın hafızası ile ilişkilidir. Yazar metnini kaçınılmaz şekilde bazı seçimler yaparak şekillendirecektir. Zira Aksoy’a göre kişi "yazım sürecinde hayatına geri dönüp baktığında onu bir bütün olarak göremez" (14). Diğer bir ifade ile "bu süreçte yazarın okura sunmak istediği portre belirleyici olacaktır. Çoğunlukla, toplumca tanınmış kişilerin hayat hikayelerini yazdığı düşün[ül]ecek olursa, yazarın kendini nasıl kurgulamak istediği, yani nasıl bir 'ben’in hikayesini anlatmak istediği daha da önem kazanır" (14).

Aksoy'un da vurguladığı üzere, otobiyografinin bir türü olarak anı yazarları da birtakım tercihlerde bulunarak var olan gerçeklikleri kendi süzgecinden geçirerek okuyucuya aktarmaktadır. Nitekim,

\begin{abstract}
bir otobiyografide kendini gösteren gerçeklik geçmişe bugünden bakarak, o geçmişi bugünün bakış açısından yeniden kurgulayan bir gerçekliktir. Otobiyografide yaşantı yeniden şekillenir, gözden geçirilir, sınırlandırılır, dönüştürülür. Bu yüzden, anlatılan "ben"in arkasındaki yazan "ben"in her zaman dikkate alınması gerekir. Çünkü anlatılan "ben”i kurgulayan kişi kimi ayrıntıları seçip kimilerini görmezden gelen o arkadaki, yazan "ben"dir. Sonuç olarak, otobiyografinin konusu tekil bir bütünlükten çok, metnin içinde kendini gösteren söylemler, o söylemlerden çıkan anlamlardır (Aksoy, 2018: 36).
\end{abstract}

Anı türüne ilişkin bu söylemlere dayanarak, Mesut Uyar’ın “Türkçe Baskıya Önsöz”de vurguladığı noktaların türün özellikleriyle son derece ilişkili olduğunu söylemek mümkündür. Bu bağlamda, ilgili metnin çeviri sürecinde, türün bu özelliklerinden kaynaklanan "taraflı” ve “öznel” anlatının nasıl ele alınacağı da önem kazanmaktadır. Zira, çeviri metnin kendisi de bu taraflılığı ve öznelliği devam ettirerek anlatının bir parçası olabilir. Bu bağlamda, çeviri metnin üretiminde aktif bir rol oynadığı görülen Uyar'ın metin boyunca düşmüş olduğu dipnotlar da ayrı bir önem kazanmaktadır. Söz konusu 
dipnotlar üzerinden yapılacak incelemeye geçmeden önce, metnin çeviribilim bağlamında bir "metinsiz geri çeviri” örneği olarak ele alınabileceğinden hareketle, kısaca "metinsiz geri çeviri” kavramına değinilecek ve kavramın yapılan gözlemlere nasıl bir katkı sağlayabileceği tartışlacaktır.

\subsection{Bir "Metinsiz Geri Çeviri” örneği olarak Esir Bir İngiliz Doktorun Kûtülamare Anzları}

"Metinsiz geri çeviri" ("textless back translation") kavramı ilk olarak "kökensiz geri çeviri” ("rootless back translation") şeklinde Çinli çeviribilimci Hongyin Wang (2009) tarafından ortaya atılmıştır (krş. Wang, 2009; aktaran Guo, 2017: 1355). İngilizce yazılmış Çin kültürünü anlatan bir romanın Çinceye çevirisi önce "kökensiz geri çeviri" olarak adlandırılmıştır. İngilizcede oluşturulan ilk metinse Çin kültürünü anlatmasına rağmen İngilizce yazılması nedeniyle "yabancı dil yaratımı" olarak kavramsallaştırılmıştır. "A Review on Textless Back Translation of China-Themed Works Written in English" (2017) isimli makalelerinde Tu ve Li, Wang tarafından "kökensiz geri çeviri" kavramının neden "metinsiz geri çeviri” olarak değiştirildiğine değinmektedir. Sözü geçen çevirilerin dilsel değil de kültürel bir geri dönüş anlamına geldiği için geri çeviri olarak adlandırıldığını ve kültürel kökenlerin korunmasından ötürü "kökensiz" değil de "metinsiz" olarak adlandırıldığı belirtilmektedir (krş. 2-3).4

Bu bilgiler ışığında Captured at Kut: Prisoner of the Turks isimli kitabın bir "yabancı dil yaratımı" örneği, Türkçeye çevirisi olan Esir Bir İngiliz Doktorun Kûtülamare Anıları'nın ise bir "metinsiz geri çeviri” örneği olduğu söylenebilir. Zira, ilgili kitap, her ne kadar bir askerin esaret dönemini anlatıyor olsa da aslında W. C. Spackman'ın dolaşım serbestliğine sahip olmasından dolayı sadece içinde bulunduğu ortamı ve koşulları değil, bölge toplumunu, kültürünü ve ilgili dönemi adeta bir seyyah gibi anlatmaktadır. Mesut Uyar da bu konuya yazmış olduğu önsözde değinmiştir:

Spackman bir seyyah gibi, gördüğü yeni yerleri ve insanları renkli bir şekilde okuyuculara aktarmaya çalışmıştır. Osmanlı İmparatorluğu'nun çokuluslu çok kültürlü yapısı ve büyük coğrafyası bir yabancı gözünden sunulmaktadır. Bildiğimizi düşündüğümüz bir ülke ve savaş hakkında Spackman sayesinde yeni şeyler öğrenme ve farklı bakış açıları görme şansı elde etmekteyiz (Uyar, 2018: xix).

İnceleme nesnesi olarak metinsiz geri çevirileri çalışmaya değer kılan önemli noktalardan bir tanesi de bu türden metinlerin çeviri süreçlerinde geleneksel anlamda kaynak ve erek metin arasında kurulan ilişkilerin konum değiştirmesidir. Ayşe Banu Karadă̆’n da vurguladığı üzere, "genelde çeviri bağlamında otoritenin telif metinlere verildiği bilinir" ancak geri çeviriler söz konusu olduğunda "otoritenin çeviri metinlerde ve bu metinlerin başlıca eyleyicileri olarak çevirmenlerde, redaktörlerde/editörlerde ve yayınevlerinde olduğu söylenebilir” (2019: 55). Dolayısıyla, incelenen bu eser bağlamında, erek kültüre ait bir geçmiş anlatısının anı türünün öznelliği dahilinde İngiliz okura sunulmasının, bir anlamda da "çevrilmesinin" ardından Türk erek dizgesine olan metinsiz geri çevirisinin de kaçınılmaz olarak erek kültürü yansıtan öznellikle şekillenmesi beklenebilir.

\section{Geçmişin anlatısında güç mücadelesinin sergilendiği bir alan olarak Esir Bir İngiliz Doktorun Kûtülamare Anıları}

Esir Bir İngiliz Doktorun Kûtülamare Anıları'na ait yan metinlerin metne nasıl yaklaşılması gerektiği hususunda okuru yönlendirici nitelikte olduğu söylenebilir. Öncelikle, metnin yayımlanma serüvenini anlatan yazar W. C. Spackman'ın yeğeni Anthony Spackman'ın, kendisinin bu anlatıdaki rolünü

4 Geri çeviri alanında Türkçe çeviribilim literatüründe yürütülmüş çalışmalar için bkz. Avşaroğlu ve Karadağ (2018); Baydere (2018); Gökduman (2018); Karadă̆ (2019). 
açıklayan -kendi görüşüne göre metne müdahalesi minimumdadır- bir önsöz ile karşılaşan okur, elindeki eserin oluşumunda yazar olarak adını gördüğü kişi dışında eyleyicilerin de var olduğunu görmektedir. Eserin Türkçe baskısına önsöz yazan yayın danışmanı Mesut Uyar'ın da Türk okuyucuların metne bakışını yönlendirecek bilgiler sunduğu söylenebilir. Uyar, öncelikle metnin esaret anılarından oluştuğu bilgisinden hareketle, esaret anılarının normal askerlik anılarından çok farklı olduğunu, esaret anılarında -kişilerin kahramanca davranışlarının anlatıldığı klasik asker anılarının aksine- askerlerin esir düşme travmasıyla baş etme ve bir nevi savunma yapma çabasında olduklarını belirtir:

\begin{abstract}
Esaret anılarının normal asker anılarından önemli farkları vardır. Klasik asker anıları temelde savaşın ağır koşulları altında bireylerin nasıl kahramanca görevlerini yapıp düşmana üstünlük sağladıklarına odaklanırlar. Görevleri ve rütbeleri ne olursa olsun bu tarz anı yazarlarının ana gayesi kahramanlıkların ve fedakarlıkların unutulmamasını sağlamaktır. Eski savaş esirleri[nin] ise bu açıdan önemli bir sıkıntıları vardır. Silah arkadaşlarının aksine onların savaş deneyimleri düşmanın eline să̆ olarak düşerek aniden ve utanç verici bir şekilde kesilmiştir. Artık düşmana karşı savaşma imkanları ellerinden alındığı gibi, cephede her gün ölümle yüz yüze gelen arkadaşlarının aksine savaş yıllarını cephe gerisinde emniyet içinde geçirmişlerdir. Bu esaret deneyimini çoğunluk için travmaya dönüştüren süreç savaşın ve esaretin bitmesiyle başlar. [...] Esaret utancı ve savaşı tehlikeden uzak geçirme travmatik olgulardır. [...] Kût gazileri için ise durum daha da kötü bir şekilde cereyan etmiştir. Çünkü onlar sadece düşman eline düşmemişler aynı zamanda İngiliz tarihinin en utanç verici yenilgilerinden birinin aktörleri olmuşlardır (Uyar, 2018: xviii-xix).
\end{abstract}

Uyar'ın bu ifadeleri yazarın aktaracağı olayların ve dönemin Türk toplumuna ilişkin sunacağı fotoğrafın nesnel doğrular olarak kabul edilmemesi yönünde bir telkin olarak değerlendirilebilir. Zira, Uyar’a göre yazar bu eserini ortaya çıkarırken arka planda işleyen farklı kaygıları söz konusu olmuştur. Aslında bu durum anı türünün özellikleri arasında da ifade edilmiştir. Ancak Uyar esaret anılarını anı türü içinde ayrı bir yere koymaktadır. Uyar, herhangi bir anıdan farklı olarak, esaret anılarını yazan kişilerin, tecrübe edilen yenilginin etkisini bir nebze olsun hafifletebilmek için çaba sarf ettiğini iddia etmektedir. Esir düşen bu askerlerin yazma eylemlerinin "prestij ve onurlarını savunma" (Uyar, 2018: xix) amacı güttüğü söylenebilir. Kût anılarında askerlerin temel iddiasını Uyar şu sözlerle özetlemektedir:

Evet esir düşmüşlerdir, ama Türklerin elinde esaret hayatı en az cephedeki kadar meşakkatli ve tehlikelidir. Yüzlerce arkadaşları çok kötü koşullar altında ölmüşsür. Üstelik düşmana boyun eğmemişler ve onunla mücadeleye kahramanca devam etmişlerdir. Dolayısıyla diğer gazilerin sahip olduğu prestij ve imtiyaza kendilerinin de sahip olduklarını iddia etmektedirler (Uyar, 2018: xix).

Bu sözlerle Uyar'ın okuru metinde karşılaşacağı bilgileri sorgulamaya yönlendirdiği iddia edilebilir. Ancak Uyar aynı zamanda W. C. Spackman'ın anılarının klasik Kût anılarından önemli farklar içerdiğini, diğerlerinin aksine Spackman’ın bütün Türkleri "kötü, tehlikeli, acayip veya firsatçı" (Uyar, 2018: xix) olarak görmediğini de belirtmektedir.

Önsöze ek olarak, ilgili esere düşülen toplam 8o dipnot bulunmaktadır. Bu dipnotlardan 38’i yayın danışmanı Mesut Uyar'a aitken, kalanlar çevirmen Derin Türkömer'e ve şiir çevirilerine ilişkin kısımlarda da editör Pınar Güven'e aittir5. Ayşe Banu Karadağ “Çevirmen ve Düzeltmen/Yayın Yönetmeni Dipnotlarıyla Osmanlı Tarihi”ni Yeniden Yazmak: Dil-içi ve Dillerarası Çeviri Örneği” (2011) isimli çalışmasında dipnotların birer diliçi çeviri örneği olarak ele alınabileceğini belirtmektedir (220). Bunun yanı sıra çeviri metindeki dipnotlar özellikle bilgilendirici olmaktan ziyade eleştirel bir nitelik taşıdıklarında karşıt iki anlatıdan oluşan bir metni doğurabilmektedir. Bu bağlamda, tarih anlatısı

2 Nisan 2019 tarihinde İş Bankası Kültür Yayınları ile yapmış olduğum yazışmadan elde ettiğim bilgilere göre, metnin içeriği ile ilgili ek bilgiler içeren dipnotlar Mesut Uyar tarafından, şiir çevirilerine ilişkin dipnotlar editör Pınar Güven tarafından, ç.n. kısaltması ile verilmiş dipnotlar çevirmen Derin Türkömer tarafından düşülmüss, kaynak metinde var olan dipnotlar ise erek metne * işareti ile taşınmıştır. 
bağlamındaki “doğru” arayışının ve güç mücadelesinin Esir Bir İngiliz Doktorun Kûtülamare Anıları başlıklı çeviri metindeki yansımaları tüketici olmamakla birlikte aşağıda sunulan ve "yayın danışmanı" Uyar tarafından düşülmüş dipnot örnekleri üzerinden irdelenecektir.

\section{Örnek 1:}

E.M. "Ancak engebeli çöle inince telgraf direklerinden birine çarpmıştı ve gözlemcisiyle birlikte yaya olarak kaçmaya çalışırlarken fellahlar tarafindan vurulmaktan kıl payı kurtulup yakalanmışlardı45.” (102)

45. Dipnot: Burada bahsedilen hadise, 13 Kasım 1915'te Osmanlı telgraf hatlarını imha etmek için yere inmiş bir İngiliz keşif uçağı ve mürettebatının yerel jandarma ve halk tarafından yakalanmasıdır. Burada bir yanlış hatırlama söz konusu: Farman modeli uçağın pilotu Avusturalyalı Yüzbaşı Thomas W. White ve İngiliz Yüzbaşı Francis Yeats-Brown ise gözlemciydi. Her ikisi de Osmanlı askerlerince sağ olarak ele geçirilmiştir. Savaş sonrasında her iki subay da anılarını yayımlamıştır. Bkz. T. W. White, Guests of the Unspeakable, Londra: John Hamilton, 1928, s. 44-53. Francis Yeats-Brown, Caught by the Turks, New York: The Macmillan Company, 1920, s. 1-25. Francis Yeats-Brown, Golden Horn, Londra: Victor Gollancz, 1932, s. 108-119. (102)

K.M. “...but on landing on the rough desert the machine unluckily collided with one of the telegraph poles and he and his observer were captured, barely avoiding being shot by fellahin during their attempted flight on foot." (9. Bölüm 10. Paragraf)

Yukarıdaki örnekte yazar W. C. Spackman, Türkler tarafından öldürülmek üzereyken hayatlarını kurtaran iki İngiliz'in durumuna ilişkin bilgi vermekteyken, bu bilgiye düşülen dipnotta olayın yazarın hatırladığından farklı cereyan ettiği, bahsi geçen uçak mürettebatından sadece birinin İngiliz olduğu ve her ikisinin de Osmanlı askerleri tarafından sağ ele geçirildiği belirtilmektedir. Bu örneğin önemli bir özelliği de dipnotta verilen diğer kaynaklardır. Çeviri metne düşülen bu dipnotlarda, konuyla ilgili görüldüğü yerlerde farklı kaynaklara göndermede bulunularak yazarın söylediğinin değil de dipnotta verilen bilginin doğru olduğuna vurgu yapılmaktadır. Bu bağlamda, dipnotlarda verilen bilgilerin kaynak metinle çeliştiği ve "mücadele" içinde olduğu durumlarda farklı kaynaklara göndermede bulunulması anlatıdaki "güç mücadelesinde" üstünlüğü elde etmeye yönelik bir teşebbüs olarak değerlendirilebilir. Diğer bir ifade ile, burada özgün metinde verilen bilgiye karşı "doğru” bilginin ne olduğuna yönelik bir arayışın söz konusu olduğunu söylemek mümkündür.

\section{Örnek 2:}

E.M. “Askerler ise bütün temel ihtiyaçlarının karşılanmasına alışık olduklarından, ellerinde bulunan nakit parayı ilerideki daha vahim zorlukları düşünmeden, keyfi veya anlık isteklere harcanabilir görüyorlardı51.” (121)

51. Dipnot: "Yazar bilerek veya bilmeyerek; subayların dönemin savaş hukuku kuralları gereğince astsubay ve erlere göre daha iyi muamele gördüğünü, kendilerine eşiti Osmanlı rütbesi karşılığında maaş verildiğini, daha çok ve daha iyi yiyecek sağlandığını, isterlerse hizmetçi asker verildiğini ihmal etmektedir. Gerçekten de Kût esirlerinin nakliyesinde ve Anadolu'daki esaret dönemlerinde subay zayiatı, astsubay ve erlerle mukayese edilmeyecek ölçüde az olmuştur.” (121)

K.M. "The troops were used to being provided with all their basic needs and were inclined to regard any loose cash as to be spent on their fancies or urges of the moment, without regard to the desperate hardships ahead." (10. Bölüm 19. Paragraf)

Yukarıdaki örnek yazarın subaylar ve rütbesiz askerler arasında zayiat açısından bir karşılaştırma yaptığı kısımdan alınmıştır. Özellikle maddi durumla ilgili verilen detaylar ile subay sınıfının daha avantajlı bir konumda olduğunu belirtmektedir. Ancak bunu savunurken de altında yatan sebepleri kendi entelektüel birikimleriyle ilişkilendirerek anlatmaktadır. Bu konuda çeviri metne düşülen dipnotta ise aslında subayların bu nispeten avantajlı konumunun dönemin savaş hukuku kuralları uyarınca sağlandığı ve Osmanlı askerlerinin sahip olduğu haklara kendilerinin de sahip olduğu bilgisi verilmektedir. Yazarın bu bilgiyi "bilerek ya da bilmeyerek" atladığını belirten dipnot, metin boyunca 
yazarın anlattı̆̆ı şartların ifade ettiği kadar kötü olmadığını gösterme ya da söz konusu durumun sebebini ortaya koyma amacını taşıması açısından son derece önemlidir.

Örnek 3:

E.M. "Ancak oradaki Türk komutanın kömür kıtllğını ileri sürerek yaptığı baskıdan dolayı askerlerin çoğu, yürüyerek on dört kilometre uzaktaki başka bir kampa gitmek zorunda kald152." (122)

52. Dipnot: "Teslim görüşmelerinde Halil Paşa esirlerin geriye sevkiyatı için İngiliz tarafından kömür talep etmişti. Eğer kömür verilmeyecek olursa esirleri yürütmekten başka çaresi olmadığını belirtmesine rağmen İngiliz tarafı bu teklifi reddetmişti. Yazarın iddiasının aksine, bu uygulama sadece İngiliz savaş esirlerine yapılmamıştır. Gerçekten kömürün az olması nedeniyle Osmanlı askerleri ve yaralıları da çoğu zaman karadan sevk edilmekteydi." (122)

K.M. "However, under pressure from the local Turkish commander, who pleaded shortage of coal, most of the men were made to march the nine miles to the camp." (10. Bölüm 21. Paragraf)

Yukarıdaki örnekte yazarın ilgili bölgede karar alıcı konumda olan Türk komutana ilişkin bir suçlaması söz konusudur. Esir alınan askerlerin kamplara sevkiyatının trenle gerçekleşmesi beklenirken, treni çalıştıracak kadar kömür olmadığından ötürü askerlerin yürümesi gerekmiştir. Çeviri metindeki dipnotta ise bu bilginin doğru olduğu, ancak sonucun böyle olmaması için Türk tarafinın belirli girişimlerde bulunduğu, buna rağmen İngilizlerin bu taleplere karşıllı vermemesinden dolayı sonucun yürüyerek sevkiyatla son bulduğu belirtilmektedir. Bu noktada Uyar'ın kaynak metinde sunulan ve suçlama içeren bilginin doğruluğuna çeviri metne koyduğu dipnotla karşı çıktığı söylenebilir.

\section{Örnek 4:}

E.M. "Savaş esirleriyle ilgili konularda subayları askerlerinden ayırmak, kabul edilmiş prensiptir. Türkler, itirazlarımıza rağmen bu prensibi esaretimiz boyunca uyguladılar53." (124)

53. Dipnot: "Savaş hukuku kurallarına göre, savaş esirlerinin askeri statülerine (subay-erat) ve cinsiyete göre ayrılıp ayrı kamplarda savaş boyunca muhafaza edilmeleri gerekmektedir. Osmanlı Ordusu, yazarın istediği gibi davranması halinde hukuk kurallarını çiğnemiş olurdu. Astsubay ve erler savaşla doğrudan ilgili olmayan işlerde çalıştırılabilirken, subayların çalışma mecburiyetleri bulunmuyordu. Subay savaş esiri kampları daha rahattı ve istihkakları daha çoktu.” (124)

K.M. "It is an accepted principle in dealing with prisoners of war to separate the officers from their men. The Turks did this despite our protests and they continued this practice throughout our captivity.” (10. Bölüm 25. Paragraf)

Yukarıdaki örnekte yazarın vurgusu subaylar ile askerlerin ayrı kamplarda tutulmasına ilişkindir. Burada, Türklerin ilgili kararı uygulaması askerlerin subaylardan ayrı tutularak daha kolay disipline edilmesi ve emir altına alınabilmesi ile ilişkilendirilmektedir. Subay olarak kendilerinin bu duruma itiraz etmelerine rağmen uygulamanın sürdürüldüğünden yakınılmaktadır. Ancak dipnotta verilen bilgi, ayrı tutulma olayının gerçekten var olmasına rağmen, yazarın ithamlarının doğru olmadığı şeklindedir. Zira, askerlerin statü ve cinsiyete göre ayrı tutulması, savaş hukuku kuralları gereği olduğu için, Uyar’a göre aksi şekilde davranılması Osmanlı Ordusunun bu kuralları çiğnemesine sebep olacaktır. Ayrıca, subayların esir bile olsalar çalışma mecburiyetleri olmadığı, oysa diğer statüdeki askerlerin çeşitli işlerde kullanılabileceği bilgisi verilerek, yazarın ithamının aksine, bu uygulamanın askerleri emir altında tutmayı kolaylaştırma adına yapılmadığı da vurgulanmaktadır.

Sonuç olarak, çeviri metin boyunca düşülen eleştirel amaçlı dipnotların yazarın anlattığı geçmişin onun anlattığı şekilde olmayabileceğini yahut öyle olsa bile bahsedilen olaylara ilişkin sebeplerin farklılık arz edebileceğini gösterme amacını taşıdı̆̆ı söylenebilir. Bu bağlamda, çeviri metinde, kaynak metinde şekillenen anlatıya karşıt bir başka anlatının daha söz konusu olduğu iddia edilebilir. Yayın danışmanı Mesut Uyar'ın çeviri sürecinde hem kaynak metnin “doğruluğunu” sorgulamaya açtığı, hem de gerekli 
gördüğü kısımlarda kendi bilgi ve kaynaklarına dayanarak ilgili durumlara açılama getirmeye çalıştığı görülmektedir. Dolayısıyla, ortak bir geçmişe yönelik bu tarihsel anlatı bağlamında çeviri metnin bir güç mücadelesi alanına dönüştüğünü söylenebilir.

\section{Sonuç gözlemleri}

Çeviriye geleneksel bakışın ikili karşıtlıkları beraberinde getirdiği ve çeviri metinlerdeki otoriteyi yazara verdiği bilinmektedir. Kaynak metindeki bilgilerin doğruluğunu sorgulamak gibi etik sorumlulukları olmadığı için çevirmenlerin bir yazar olarak görülemeyeceği iddia edilmektedir (Pym, 2009). Çevirilerin üretildikleri zaman ve koşullardan bağımsız düşünülerek çeviri sürecinde etkin rol oynayan ideolojik etkenlerin yeterince dikkate alınmamasına neden olan bu bakış açısı dahilinde çevirmenler ile yazarların iş birliği içinde olmasının ve kaynak metinde yakalanması beklenen "sadık" mesajın erek okuyucuya iletilmesinin idealize edildiği söylenebilir. Bu çalışmanın bulgularının ise çeviri ürünlerin oluşumunun tek boyutlu olmadığını ve geleneksel olarak kaynak metin ile çeviri metin arasında yazarlık ve otorite bağlamında kurgulanan yapıların genel geçer bir niteliğinin bulunmadığını ortaya koyduğu söylenebilir.

Anı yazılarının kaynağının gerçek hayat olması bu türden metinlerin belirli dönemlerde olan biteni farklı bir perspektiften değerlendirme imkânı vermesi açısından önem kazanmasına neden olmaktadır. Ancak, türün özelliklerinden ötürü, son derece öznel metinlerin oluşturulduğu, bu bağlamda metinleri üreten kişilerin kişisel gündemlerinin de ilgili metinlerin değerlendirilmesinde dikkate alınması gerektiği iddia edilmektedir (Aksoy, 2018; Uyar, 2018). Esir Bir İngiliz Doktorun Kûtülamare Anılar başlıklı çeviri metin ve kaynak metni için de bu tespitlerin geçerli olduğu söylenebilir. Zira, kaynak metin uzun yıllar sonra düzenlenip kitap haline getirilmiş; hem yazarın hem de yazarın yeğeninin ve diğer esir düşmüş askerlerin de aralarında bulunduğu bir grup kişinin perspektifiyle şekillenmiştir. Metnin üretim sürecinde bahsi geçen eyleyicilerin aktif bir rol oynadığı söylenebilir. Bunun ise geleneksel bakış açısıyla otoriteyi yazara atfeden anlayışın sorgulanmasını gerektirdiği iddia edilebilir. Nitekim kolektif bir şekilde üretilen bu metnin otoritesinin sadece W. C. Spackman'da olduğunu söylemek, metnin üretim sürecini şekillendiren diğer eyleyicileri göz ardı etmek anlamına gelecektir. Bu anlamda, "doğruyu" bilen ve onun kontrolüne dair otoriteyi elinde bulunduran tek bir yazardan söz etmenin mümkün olmadığı söylenebilir.

Metnin İngilizce dilinde yazılmış olmakla birlikte dönemin Türk toplumu ve kültürüyle Türk topraklarında olanları anlatması bir "metinsiz geri çeviri” olarak ele alınmasını sağlamaktadır. Geleneksel açıdan bakıldığında durum bu şekilde olmasa da metinsiz geri çevirilerde otoritenin özgün metinlerde değil de çeviri metinlerde olduğu belirtilmektedir (Karadağ, 2019: 55). Farklı bir dilde yazılmış olan bu metinler çeviri süreciyle anlattıkları dile ve kültüre bir geri dönüş yaşadığı için, çeviri sürecinin eyleyicileri bahsi geçen kültürün temsilcileri olarak kendilerini "kültürel özgünlük konusunda yetkili, otorite sahibi” (55) olarak görmektedir. Bu anlamda, Uyar'ın Esir Bir İngiliz Doktorun Kûtülamare Anıları'na yazdığı önsöz ve metin boyunca düştüğü dipnotlar, bahsi geçen "otorite sahipliğ̈i" iddiasının yansımaları olarak değerlendirilebilir.

Arrojo’ya göre “üst-alt' ya da 'güçlü-zaylf' karşıtlığı içerisindeki dil ve kültürleri içerip de 'şeffaf' olmayı ve 'özgün’e ve sahip olduğu bağlama körü körüne bağlı kalmayı taahhüt eden her çeviri kaçınılmaz şekilde bu karşıtlıkları yapılandırmış olan genel asimetrik örüntüyü yeniden üretmekte ve güçlendirmektedir” (krş. 1997: 18). Esir Bir İngiliz Doktorun Kûtülamare Anıları, esir düşen bir İngiliz tarafından, kendisini esir alan tarafa ilişkin yazılmış bir eserdir. Güç ilişkileri bakımından değerlendirildiğinde, alt konumda olanın üst konumda olana yönelik düşüncelerini ve tecrübelerini 
anlatan bir eser olduğu söylenebilir. Oysa ki, geleneksel anlayış dahilinde, çeviri sürecinde kaynak metin üst konumda, çeviri metin ise ikincil konumda görülmektedir. Bu anlayış dahilinde, kitabın çeviri sürecinden geçmesinin ast-üst konumlarını tam tersi yönde değiştirmesi beklenebilecektir. Ancak, hem metin türünün beraberinde getirdiği özellikler nedeniyle hem de ilgili döneme ve olaylara ilişkin farklı kaynakların var olmasından dolayı, bu metin özelinde çeviri süreci beklenen şekilde bir konum değişikliğine sahne olmamıştır. Zira, çeviri metnin üretim sürecine dahil olan eyleyicilerinden biri olan yayın danışmanı, metne yazmış olduğu önsöz ve metin boyunca düşmüş olduğu dipnotlarla bir karşıt söylem oluşturarak sürece müdahil olduğunu görünür kılmıştır. Diğer bir ifade ile, çeviri eserin "şeffaf" olmayarak ve özgüne "körü körüne" bağlı kalmayarak kaynak metnin içeriğini sorgulamaya açttğı ve okuyucuları da bu sorgulamaya davet ettiği söylenebilir.

Arrojo, "rolünün farkında olan ve yorumunun altında yatan sebepleri, bağlllıkları ve tavizleri mümkün olduğunca net bir şekilde ortaya koyan görünür çevirmen[in], ürettiği metin için sorumluluk alması gerek[tiğini]" savunmaktadır (1997: 18). Çevirmen tarafından olmasa da çeviri sürecinin bir diğer eyleyicisi olarak yayın danışmanı tarafından okuyucuya ek bilgiler sunulması ve metnin okur üzerindeki etkisinin dipnotlar ile yönlendirilmesi belirtilen türden bir sorumluluğun yansıması olarak değerlendirilebilir. Bu da çevirilerin saydam aktarım süreçleri olarak değil, üretim süreci içerisindeki koşulları göz önünde bulundurularak değerlendirilmesinin önemini bir kez daha ortaya koymaktadır. Zira, kişinin belki de üzerinde en çok hak talep edebileceği anı türündeki bir metnin ve çevirisinin oluşumunda dahi hem kaynak hem de erek dizgede çok sayıda eyleyicinin rol oynadığı görülmektedir. Bu anlamda, özellikle kendisi de bir "yeniden yazım” olan tarih yazımının (Lefevere, 1992: 9) bir parçası olarak değerlendirilebilecek anı yazılarında "doğru” olana ilişkin otoritenin tek bir kişinin mahiyetinde olmadığı ve hem bu türdeki kaynak metinlerin hem de çevirilerinin farklı düzey ve niteliklerde güç mücadelelerine ve otorite sahipliği iddialarına sahne olduğu savunulabilir.

\section{Kaynakça}

Aksoy, N. (2018). Kurgulanmış Benlikler: Otobiyografi, Kadın, Cumhuriyet. İstanbul: İletişim Yayınları.

Arrojo, R. (1997). Asymmetrical Relations of Power and the Ethics. Text-Context, 11, 5-24.

Arrojo, R. (1998). The Revision of the Traditional Gap between Theory \& Practice \& the Empowerment of Translation in Postmodern Times. The Translator, 4 (1), 25-48.

Arrojo, R. (2002). Writing, Interpreting and the Control of Meaning. E. Gentzler ve M. Tymoczko (Ed.), Translation and Power (ss. 63-79). Amherst: University of Massachusetts Press.

Avşaroğlu, M. ve Karadă̆, A. B. (2018, Aralık). Tarihsel Romanların (Geri) Çevirileri Üzerine Betimleyici Bir Çalışma. V. Yıldız Sosyal Bilimler Kongresi’nde Sunulan Sözlü Bildiri, İstanbul.

Baydere, M. (2018). Geri Çevirilerde Çevirmenin İzini Sürmek. S. Taş (Ed.), Çeviribilimde Güncel Tartışmalardan Kavramsal Sorgulamalara (ss. 317-347). İstanbul: Hiperlink Yayınları.

Bulut, A. (2000). Çeviri Metnin Değerlen(dir)mesi: Metinsel (Eş) değer(lik) Anahtarları. Hacettepe Çeviribilim ve Uygulamaları Dergisi, (10), 73-88.

Bush, P. (2012). Toil, Trouble and Jouissance: A Case Study - Editing Juan the Landless. R. Wilson ve L. Gerber (Ed.), Creative Constraints: Translation and Authorship (ss. 119-135). Victoria: Monash University Publishing.

Chesterman, A. ve Arrojo, R. (2017). Shared Ground in Translation Studies. A. Chesterman (Ed.), Reflections on Translation Theory: Selected papers 1993 - 2014 (ss. 17-24). Amsterdam ve Philadelphia: John Benjamins.

Derrida, J. (1982). Positions (A. Bass, Çev.). Chicago: The University of Chicago Press. 
Gökduman, U. C. 'Yabancı Dil Yaratımı' ve 'Kökensiz Geri Çeviri’ Kavramları Üzerinden Bir Çeviriyi Okumak. S. Taş (Ed.), Çeviribilimde Güncel Tartışmalardan Kavramsal Sorgulamalara (ss. 347378). İstanbul: Hiperlink Yayınları.

Guo, T. (2017). On Foreign Language Creation and Rootless Back Translation - A Case Study of Snow Flower and the Secret Fan. Journal of Literature and Art Studies, 7 (10), 1354-1364.

Hermans, T. (1997). Çeviri Anlatıda Çevirmenin Sesi (A. Bulut, Çev.). Kuram, (15), 63-68.

Hermans, T. (2014). Translation Studies and a New Paradigm. T. Hermans (Ed.), The Manipulation of Literature: Studies in Literary Translation (ss. 7-15). New York: Routledge.

Karada $\breve{g}$, A. B. (2003). Edebiyat ve Kültür Dizgesini Şekillendirmede ‘İdeolojik’ Açıdan Çevirinin ve Çevirmenin Rolü. Doktora Tezi. İstanbul Üniversitesi Sosyal Bilimler Enstitüsü.

Karadağ, A. B. (2006). Disiplinlerarası Etkileşim Bağlamında Dilbilim-Çeviribilim İlişkisine Genel Bir Bakış. Dilbilim, 15 (1), 251-262.

Karadă̆, A. B. (2011). Çevirmen ve Düzeltmen/Yayın Yönetmeni Dipnotlarıyla Osmanlı Tarihi'ni Yeniden Yazmak: Dil-içi ve Dillerarası Çeviri Örneği. İ. Sığırcı, A. Güneş ve Z. Tok (Ed.), I. Uluslararası Çeviribilim ve Terimbilim Kurultayı Bildiri Kitabı (ss. 212-222). Kırıkkale: Vizyon Ofset.

Karadağ, A. B. (2019). Çeviri Yoluyla Geçmiş, Şimdi ve Gelecek Arasında Köprüler Kurmak. S. Taş. (Ed.), Çeviribilimde Araştırmalar (ss. 31-59). İstanbul: Hiperlink Yayınları.

Lefevere, A. (1992). Translation, Rewriting, and the Manipulation of Literary Fame. Londra ve New York: Routledge.

Pym, A. (2009). The Translator as Non-Author, and I am Sorry about That. C. Buffagni, B. Garzelli ve S. Zanotti (Ed.), The Translator as Author: Perspectives on Literary Translation (ss. 31-45). Berlin: Lit Verlag.

Spackman, A. (2008). Preface. W. C. Spackman, Captured at Kut, Prisoner of the Turks: The Great War Diaries of Colonel Wiliam. South Yorkshire: Pen \& Sword Military.

Spackman, A. (2018). Sunuş. W. C. Spackman, Esir Bir İngiliz Doktorun Kutülamare Anıları (Derin Türkömer, Çev.) (ss. xiii-xv). İstanbul: İş Bankası Kültür Yayınları.

Spackman, W. C. (2008). Captured at Kut: Prisoner of the Turks. South Yorkshire: Pen \& Sword Military.

Spackman, W. C. (2018). Esir Bir İngiliz Doktorun Kûtülamare Anıları (Derin Türkömer, Çev.). İstanbul: İş Bankası Kültür Yayınları.

Tu, Q. ve Li, C. (2017). A Review on Textless Back Translation of China-Themed Works Written in English. Studies in Literature and Language, 14(1), 1-7.

Uyar, M. (2018). Türkçe Baskıya Önsöz. W. C. Spackman, Esir Bir İngiliz Doktorun Kutülamare Anıları (Derin Türkömer, Çev.) (ss. xvii-xxi). İstanbul: İş Bankası Kültür Yayınları.

Vermeer, H. J. (2000). Skopos and Commission in Translational Action. L. Venuti (Ed.), The Translation Studies Reader (ss. 221-232). Londra: Routledge.

Wakabayashi, J. (2010). Fictional Representations of Author-Translator Relationships. Translation Studies, 4 (1), 87-102. 